\title{
Source of The Reservation In Relation To Increase Volume of Room Sales On Discovery Kartika Plaza Hotel
}

\author{
Ni Luh Novi Suryantini Dewi ${ }^{\mathrm{a}, 1, *}$, I Gusti Agung Mas Krisna Komala Sari ${ }^{\mathrm{b}, \mathrm{c}, 2}$, I Nyoman Winia ${ }^{\mathrm{b}, 3}$ \\ ${ }^{a}$ Ni Luh Novi Suryantini Dewi, Giri Dharma Camplik (GWK) Street Gg. Yudistira No. 02 Ungasan, South Kuta, Badung \\ and 80361, Indonesia \\ ${ }^{b}$ I Gusti Agung Mas Krisna Komala Sari, Pandu Street No. 03 Dalung, Badung and 80363, Indonesia \\ ${ }^{1}$ novidewi090@gmail.com *; ${ }^{2}$ gungmaskrisna88@gmail.com ; ${ }^{3}$ nyomanwinia@pnb.ac.id
}

ARTICLE INFO

Article history:

Received: October 16, 2020

Reviewed: November 11, 2020

Accepted: November 28, 2020

Published: December 21, 2020

Keywords:

Multiple Regression Analysis, Online Travel Agent, Offline Travel Agent, FIT, Group, Room Sales Volume.

\section{ABSTRACT}

Discovery Kartika Plaza Hotel establishing cooperation with several source of reservations such as online travel agents, offline travel agents, free independent travelers (FIT) and groups in increasing volume room sales to win the competition between 5-stars hotels in Kuta. Data obtained through observation, interviews, library research and documentation. Data analysis is performed by quantitative analysis of secondary data, such as; partial correlation analysis, multiple correlation analysis, classic assumption test, multiple linear regression test, hypothesis test analysis, multiple determination coefficients, standardized coefficient beta statistical analysis, and effective contribution with the help of SPSS version 23. Based on the results of the analysis, partially there is a significant influence positive and significant between online travel agents for room sales volume with p-value $0.000<0.05$, offline travel agent for room sales volume with p-value $0.000<0.05$, FIT for room sales volume with $\mathrm{p}$ value $0.000<0.05$ and group for volume room sales with $\mathrm{p}$-value $0,000<0.05$. Also, online travel agents, offline travel agents, FIT and groups have a positive and simultaneous effect on room sales volume with p-value $0,000<0.5$ and total value of effective contributions of $99.2 \%$. The most dominant variable is the offline travel agent with an Effective Contribution value of $45.83 \%$.

Copyright (c) 2019 Politeknik Negeri Samarinda. All rights reserved.

\section{Introduction}

Discovery Kartika Plaza Hotel promotes and cooperates with source of reservations such as online travel agents, offline travel agents, FIT and Group to get high room sales volumes. Currently, online travel agents can be said to have a large impact on room sales to increase the volume of hotel room sales through online promotions (Inversini \& Masiero, in Wachyuni et al, 2018). The Occupancy target that has been set at Discovery Kartika Plaza Hotel itself is $70 \%$ for each year. But if seen from the last three years, Discovery Kartika Plaza Hotel has not been able to optimally meet the occupancy target because in 2017 the occupancy achieved was only $63.13 \%$, for 2018 it was $65.84 \%$ and in 2019 it was $67.53 \%$. From this background, the researchers wanted to find out how the influence of source of reservations to increase room sales volume and which source of reservations were most dominant in increasing volume room sales at Discovery Kartika Plaza Hotel.

\section{Review Related Literature}

The theoretical basis in this research is that reservation is a section in the front office department whose duties and responsibilities handle booking requests from prospective guests According to Bagyono, Krestanto, (2019). Source of reservation according to Bagyono (2014: 106) is a person or parties who are the source of the reservation coming. These sources constitute the fabric of cooperation as outlined in the form of a cooperation contract. According to Bagyono (2014: 60), a travel agent is a commercial business activity that regulates, provides, and

W : http://e-journal.polnes.ac.id/index.php/edutourism/

E : jurnal_edutourism@polnes.ac.id 
organizes services aimed at a person or group of people, which are carried out entirely with the main objective being to get a profit. Online Travel Agent according to Yoeti in Satyawan (2017: 28) is one type of travel agent that carries out its activities online. Whereas Offline Travel Agent is a travel agent whose sales are carried out not through online media but brochures or banners. For FIT, some people travel privately or not with a group. But for the Group are people who travel in the form of groups or groups. For groups, it is usually included in the tour package.

Sales according to Budi Raharjo (2007: 79) in Mufidah (2016) are the most important main source of income, usually always placed in the first line of the Profit-Loss calculation. Sales volume according to Marbun (2003: 255) in Rustami (2014) sales volume is the total goods sold by the company within a certain period. The greater the number of sales the company makes, the more likely it is that the profit will be made by the company. Hotels according to Rumekso (2009: 1). is a building that provides guests with a room to stay, food, and drinks, as well as necessary facilities, and is professionally managed for profit.

\section{Research Methodology}

This study uses 2 variables namely, independent variables and dependent variables. According to Sugiyono (2014: 39), the independent variable is a variable that affects or becomes the cause of the change or the emergence of the dependent variable. Included in the independent variables in this study are the Online Travel Agent, Offline Travel Agent, FIT, group. As for the dependent variable according to Sugiyono (2014: 39), the dependent variable is the variable that is affected or is the result, because of the independent variables, in this study the dependent variable is the volume of room sales.

This research uses quantitative and qualitative analysis techniques. Quantitative data is data in the form of numbers or quantitative data that is used for scoring used in research (Sugiyono, 2015:28) while qualitative data is data in the form of sentences, words, gestures, facial expressions, charts, a photograph or picture
(Sugiyono, 2015: 28). This study uses multiple linear regression analysis.

\section{Results and Discussion}

\section{Descriptive Statistics}

\begin{tabular}{|l|r|r|r|r|r|r|r|}
\hline & \multicolumn{1}{|c|}{ Descriptive Statistics } \\
\hline & \multicolumn{1}{|c|}{ N } & Range & Minimum & Maximum & \multicolumn{1}{c|}{ Mean } & \multicolumn{1}{c|}{$\begin{array}{c}\text { Std. } \\
\text { Deviation }\end{array}$} & \multicolumn{1}{c|}{ Variance } \\
\hline Volume Peniualan & 36 & 5605 & 3157 & 8762 & 6290.42 & 1355.781 & 1838142.764 \\
Kamar & 36 & 4402 & 834 & 5236 & 1997.03 & 1026.739 & 1054193.685 \\
Offline & 36 & 3109 & 483 & 3592 & 1750.08 & 893.308 & 797998.879 \\
Online & 36 & 1985 & 16 & 2001 & 1318.53 & 389.161 & 151446.485 \\
Group & 36 & 599 & 226 & 825 & 559.03 & 155.043 & 24038.199 \\
FIT & 36 & & & & & & \\
Valid N (listwise) & &
\end{tabular}

Figure 1. Descriptive statistics from SPSS 23 data processing results, 2020.

Based on the above picture the data studied amounted to 36 months from the period January 2017 to December 2019 at the Discovery Kartika Plaza Hotel. The lowest achievement generated by the online travel agent variable is 483 room nights, while the highest achievement is 3,592 room nights. Where the average monthly contribution from online travel agents can produce between 857 room nights to 2,643 room nights.

The lowest achievement generated by the offline travel agent variable is 834 room nights, while the highest achievement is 5,236 room nights. Where the average monthly contribution from offline travel agents can produce between 971 room nights and up to 3,023 room nights.

The lowest achievement generated by the variable independent free traveler (FIT) is equal to 226 room nights, while for the highest achievement produces 825 room nights. Where the average monthly contribution from free independent travelers (FIT) can produce between the range of 404 room nights to 714 room nights.

The lowest achievement generated by the group variable is 16 room nights, while the highest achievement is 2001 room night. Where the average monthly contribution from the group can produce between the range of 929 room nights to 1,707 room nights. The lowest achievement generated by the variable room sales volume is 3,157 room nights, while the highest achievement is 8,762 room nights. Where the average monthly contribution from room sales volume can produce between 4,935 room nights to 7,645 room nights. 


\section{Analysis of Partial Correlation Coefficients}

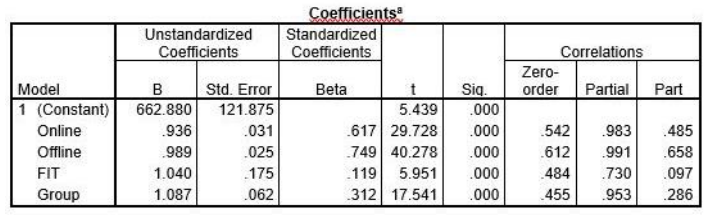

Figure 2. Analysis of partial correlation coefficients from SPSS 23 data processing results, 2020.

From the picture above, it can be seen that the relationship between the independent variable and the dependent variable can be seen in the results of the partial correlation on the online travel agent of 0.983 , which means that there is a positive and very strong relationship partially with the volume of room sales. The result for an offline travel agent is 0.991 which means that there is a positive and very strong relationship partially with room sales volume. For FIT results of 0.730 which means that there is a positive and strong partial relationship to room sales volume. And for groups with results of 0.953 which means that there is a positive and very strong relationship partially with room sales volume. room nights.

\section{Analysis of Multiple Correlation Coefficients}

\begin{tabular}{|c|c|c|c|c|c|}
\hline \multicolumn{6}{|c|}{ Model Summari: } \\
\hline Model & $\mathrm{R}$ & R Square & Adjusted R Square & $\begin{array}{l}\text { Std. Error of the } \\
\text { Estimate }\end{array}$ & Durbin-Watson \\
\hline 1 & $.996^{4}$ & & 991 & 130.94578 & 1.75 \\
\hline
\end{tabular}

Figure 3. Analysis of multiple correlation coefficients from SPSS 23 data processing results, 2020.

The picture above shows the value of multiple correlation coefficients can be seen from the results of $\mathrm{R}$ which is equal to 0.996 which is in the range of coefficients 0.80 1,000 , so it can be concluded that there is a positive and very strong correlation relationship together - simultaneously between independent variables namely online travel agent, offline travel agent, FIT, and group to the dependent variable, towards room sales volume.

\section{Classic Assumption Test a. Normality Test}

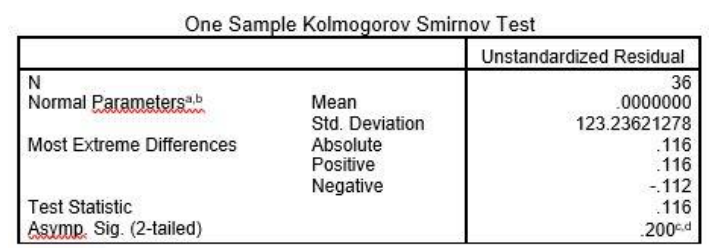

Figure 4. Normality test from SPSS 23 data processing results, 2020.

From the picture above it can be seen that the results of the normality test on the OneSample Kolmogorov-Smirnov Test in this study can be seen from the Asymp value. Sig. (2-tailed) of .200. Then it can be concluded that overall the above data has met the assumption of normality since the data is above significant 0.05 or (a)> 0.05 , which means normally distributed.

\section{b. Linearity Test}

\begin{tabular}{|l|l|l|l|}
\hline \multicolumn{1}{|c|}{ Variabels } & \multicolumn{1}{c|}{$F$} & \multicolumn{1}{c|}{ Sig } & \multicolumn{1}{c|}{ Information } \\
\hline Online Travel Agent & 14.124 & .001 & Linear \\
\hline Offline Travel Agent & 20.342 & .000 & Linear \\
\hline FIT & 10.417 & .003 & Linear \\
\hline Group & 8.875 & .005 & Linear \\
\hline
\end{tabular}

Figure 5. Linearity test from SPSS 23 data processing results, 2020.

From the picture above, the linearity test using the Curve Estimation method obtains the significance value between each independent variable to the dependent variable as follows: online travel agent (X1) to room sales volume $(\mathrm{Y})$ of 0.001 , the offline travel agent (X2) to sales volume rooms (Y) by 0,000 , FIT (X3) to room sales volume $(\mathrm{Y})$ by 0,003 , and group $(\mathrm{X} 4)$ to room sales volume $(\mathrm{Y})$ by 0,005 . So based on the results of the Curve Estimation it is known that the four independent variables get probability values $\leq 0.05$ which means that there is a linear relationship between each independent variable to the dependent variable. 


\section{c. Heteroscedasticity Test}

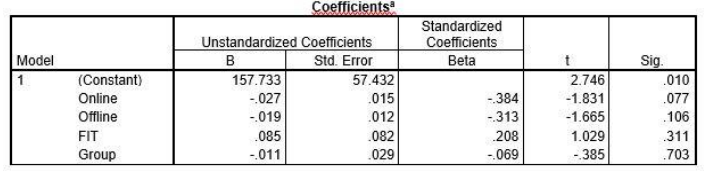

Figure 6. Heteroscedasticity test from SPSS 23 data processing results, 2020.

The picture above can be seen from the results of the heteroscedasticity test on the glacier model in this study resulting in a significance of 0.077 for online travel agents, then for offline travel agents for 0.106, for the FIT of 0.311 and groups of 0.703 . Then it can be concluded that the whole of the above data is said to not occur heteroscedasticity because all variables have significant values above 0.05 or $(\mathrm{a})>0.05$.

\section{d. Multicollinearity Test}

\begin{tabular}{|c|c|c|c|c|c|c|c|c|}
\hline \multirow{2}{*}{\multicolumn{2}{|c|}{ Model }} & \multicolumn{2}{|c|}{$\begin{array}{c}\text { Unstandardized } \\
\text { Coefficients }\end{array}$} & \multirow{2}{*}{$\begin{array}{c}\begin{array}{c}\text { Standardized } \\
\text { Coefficients }\end{array} \\
\text { Beta }\end{array}$} & \multirow[b]{2}{*}{$t$} & \multirow[b]{2}{*}{ Sig. } & \multicolumn{2}{|c|}{ Collinearity Statistics } \\
\hline & & $\mathrm{B}$ & Std. Error & & & & Tolerance & $\mathrm{VIF}$ \\
\hline 1 & (Constant) & 662.880 & 121.875 & & 5.439 & .000 & & \\
\hline & Online & .936 & .031 & .617 & 29.728 & .000 & .619 & 1.615 \\
\hline & Offline & .989 & .025 & .749 & 40.278 & .000 & .772 & 1.296 \\
\hline & FIT & 1.040 & .175 & .119 & 5.951 & .000 & .667 & 1.500 \\
\hline & Group & 1.087 & .062 & .312 & 17.541 & .000 & .842 & 1.188 \\
\hline
\end{tabular}

Figure 7. Multicollinearity test from SPSS 23 data processing results, 2020.

Based on the picture above, it can be seen that the tolerance value of online travel agents is 0.619 , offline travel agents are 0.772 , FIT is 0.667 and the Group is 0.842 . Whereas the VIF value of online travel agent was 1,615 , the offline travel agent was 1,296 , FIT was 1,500 and the group was 1,188 . Then it can be seen from the value that it can be said that there is no multicollinearity in the regression model because of the tolerance value $>0.1$ and the VIF value $<10$.

\section{e. Autocorrelation Test}

\begin{tabular}{|l|r|r|r|r|r|}
\hline Model Summary \\
\hline Model & \multicolumn{1}{|c|}{ R } & R Square & Adiusted R Square & $\begin{array}{c}\text { Std. Error of the } \\
\text { Estimate }\end{array}$ & Durbin-Watson \\
\hline 1 & $996^{2}$ & .992 & .991 & 130.94578 & 1.757 \\
\hline
\end{tabular}

Figure 8. Autocorrelation test from SPSS 23 data processing results, 2020.

From the above picture, it can be seen from the results of the autocorrelation test using Durbin-Watson obtained a value of 1.757 which means that there is no autocorrelation because the $\mathrm{D}-\mathrm{W}$ value is between -2 to +2 .

\section{Modeling Multiple Linear Regression}

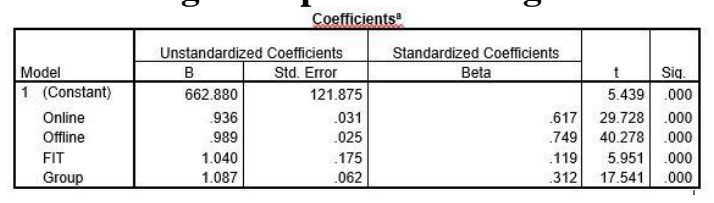

Figure 9. Multiple linear regression from SPSS 23 data processing results, 2020.

$$
\begin{aligned}
& \mathrm{Y}=\mathrm{a}+\mathrm{b} 1 \mathrm{X} 1+\mathrm{b} 2 \mathrm{X} 2+\mathrm{b} 3 \mathrm{X} 3+\mathrm{b} 4 \mathrm{X} 4 \\
& \mathrm{Y}=662,880+0,936 \mathrm{X} 1+0,989 \mathrm{X} 2+ \\
& 1,040 \mathrm{X} 3+1,087 \mathrm{X} 4
\end{aligned}
$$

From the data, the equation can be explained as follows the constant values in this study amounted to $662,880 \approx 663$ can be interpreted if all the free variables do not make a contribution or a constant with a value of zero ( 0 ) then the amount of room sales volume is equal to 663 room night.

If the constant value of the online travel agent is $0.963 \approx 94$ or it can be said that the online travel agent has increased 100 times, the total room sales volume will increase by 757 room night, with the offline travel agent, FIT and Group considered zero.

When the constant value of the offline travel agent is $0.989 \approx 99$ or it can be said that the offline travel agent has increased by 100 times, the total room sales volume will increase by 762 room nights, with online travel agents, FIT and Group considered zero.

On the other hand, the constant value of the FIT is $1,040 \approx 104$ or it can be said that the FIT has increased by 100 times, so the total room sales volume will increase by 767 room nights, with online travel agents, offline travel agents and groups considered zero.

And for the constant value in the group of $1,087 \approx 109$ or it can be said that FIT has increased by 100 times, the total room sales volume will increase by 772 room night, with an online travel agent, offline travel agent and FIT considered zero. 


\section{Hypothesis Test}

a. $\mathbf{T}$ test

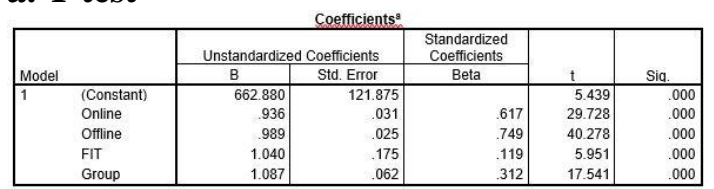

Figure 10. T test from SPSS 23 data processing results, 2020.

If seen from the picture above in column $t$ there is a calculated $t$ value of each independent variable that is online at 29.728, offline at 40.278, FIT at 5.951, and Group at 17.541. As for the $t$ table value, a value of 1.695 can be obtained from the calculation of the degree of freedom. Then it can be stated that all independent variables have the value of $\mathrm{t}$ count $>\mathrm{t}$ table which means that $\mathrm{H}_{0}$ is rejected and $\mathrm{H}_{\mathrm{a}}$ is accepted and when seen from the significant value of each variable that is equal to 0,000 which means the value of sig. (a) $<0.05$ so that it can be concluded that all independent variables both online travel agent, offline travel agent, FIT, and the group have a positive and partially significant effect on the dependent variable, namely room sales volume at Discovery Kartika Plaza Hotel.

\section{b. F Test}

\begin{tabular}{|ll|r|r|r|c|c|}
\hline Model & & Sum of Squares & \multicolumn{1}{|c|}{ df } & Mean Square & F & Sig. \\
\hline 1 & Regression & 63803446.005 & 4 & 15950861.501 & 930.253 & $.000^{\circ}$ \\
& Residual & 531550.745 & 31 & 17146.798 & & \\
& Total & 64334996.750 & 35 & & & \\
\hline
\end{tabular}

Figure 11. F test from SPSS 23 data processing results, 2020.

Based on the picture above, it can be seen that the calculated $F$ value is 930,253 and the $\mathrm{F}$ table value is 2.68 which means that $\mathrm{F}$ count> $\mathrm{F}$ table $(930,253>2.68)$ so that $\mathrm{H}_{0}$ is rejected and $\mathrm{H}_{\mathrm{a}}$ is accepted and from the above table a significant value is obtained in the test $f$ (simultaneous) of 0,000 , which means (a) $<0.05$. It can be concluded that the four independent variables namely, online travel agent, offline travel agent, FIT, and group influence positively and jointly or simultaneously on the dependent variable namely room sales volume.

\section{Coefficient Determination Test}

\begin{tabular}{|l|r|r|r|r|r|}
\hline Model & \multicolumn{1}{|c|}{ R } & \multicolumn{1}{|c|}{ R Square } & Adjusted R Square & $\begin{array}{c}\text { Std. Error of the } \\
\text { Estimate }\end{array}$ & Durbin-Watson \\
\hline 1 & $.996^{\circ}$ & .992 & .991 & 130.94578 & 1.757 \\
\hline
\end{tabular}

Figure 12. Coefficient determination test from SPSS 23 data processing results, 2020.

If seen from the Adjusted R Square results above, it can be seen that the magnitude of the influence of reservoir sources through online travel agents, offline travel agents, FIT, and groups on room sales volume at Discovery Kartika Plaza Hotel is $99.1 \%$. While the remaining $0.9 \%$ is influenced by other factors not examined in this study such as Complimentary room, affiliate staff, owner, and Celebrity stay experience.

\section{Effective Contribution}

\begin{tabular}{|l|r|r|c|}
\multicolumn{1}{|c|}{ Yariabel } & $\begin{array}{c}\text { Koefisen Berganda } \\
\text { (Beta) }\end{array}$ & $\begin{array}{c}\text { Koefisien Korelasi } \\
(\mathrm{r})\end{array}$ & R Square \\
\hline Online & .617 & .542 & \multirow{2}{*}{.992} \\
\hline Offline & .749 & .612 \\
\cline { 1 - 3 } FIT & .119 & .484 & \\
\hline Group & .312 & .455 & \\
\hline
\end{tabular}

Figure 13. Effective contribution test from SPSS 23 data processing results, 2020.

Based on the picture above to find out the value of the effective contribution made from each of the independent variables can be done with the following calculation:

Formula: SE (X)\% = Betax X Correlation Coefficient X 100\%

Then the effective contribution (SE) obtained from online travel agents was $33.44 \%$, offline travel agents were $45.83 \%$, FIT was $5.75 \%$ and the group was $14.19 \%$. So, if seen from the comparison obtained from each value of the effective contribution of the four independent variables from online travel agents, offline travel agents, FIT, and groups, it can be concluded that the independent variables that have the most dominant influence in increasing the volume of room sales at Discovery Kartika Plaza Hotel are an offline travel agent with the highest value of an effective contribution of $45.83 \%$. Then it was concluded that Offline Travel Agent was able to influence $45.83 \%$ of the total reservation amounting to $99.2 \%$ of the room sales volume at the Discovery Kartika Plaza Hotel. 


\section{Conclusion}

Based on the results of research that has been done, it can be concluded as follows:

1. From the results of the hypothesis test, it can be concluded that each of the independent variables namely Online travel agent, Offline travel agent, FIT, and Group has a positive and significant effect partially, also has a positive and significant effect simultaneously on the room sales volume at Discovery Kartika Plaza Hotel.

2. From the test results of multiple linear regression analysis, it can be concluded that the constant value in this study is $662,880 \approx$ 663 can be interpreted if all free variables do not make a contribution or a constant with zero value (0) then the amount of room sales volume is equal to 663 room night. If the constant value of the online travel agent is $0.963 \approx 94$ or it can be said that the online travel agent has increased 100 times, the total room sales volume will increase by 757 room night, with the offline travel agent, FIT and Group considered zero. When the constant value of the offline travel agent is $0.989 \approx 99$ or it can be said that the offline travel agent has increased by 100 times, the total room sales volume will increase by 762 room nights, with online travel agents, FIT and Group considered zero. On the other hand, the constant value of the FIT is $1,040 \approx 104$ or it can be said that the FIT has increased by 100 times, so the total room sales volume will increase by 767 room nights, with online travel agents, offline travel agents and groups considered zero. And for the constant value in the group of $1,087 \approx 109$ or it can be said that FIT has increased by 100 times, the total room sales volume will increase by 772 room night, with an online travel agent, offline travel agent and FIT considered zero.

3. From the calculation of the Effective Contribution (SE), it can be concluded that the independent variable that has the most dominant influence in increasing the volume of room sales at the Discovery Kartika Plaza Hotel is the offline travel agent with the highest value of the effective contribution of $45.83 \%$. Then it was concluded that Offline Travel Agent was able to influence $45.83 \%$ of the total reservation amounting to $99.2 \%$ of the room sales volume at the Discovery Kartika Plaza Hotel.

\section{References}

[1] Bagyono. 2014. Pariwisata dan Perhotelan. Cetakan Keempat. Bandung: Alfabeta

[2] Krestanto, H. 2019. Strategi dan Usaha Reservasi untuk Meningkatkan Tingkat Hunian di Grand Orchid Hotel Yogyakarta. JURNAL MEDIA WISATA: Wahana Informasi Pariwisata, 17(1).

[3] Mufidah, F., \& Apriyani, Y. 2016. Pengaruh Harga Jual Terhadap Volume Penjualan Pada Perusahaan Properti Yang Terdaftar Di Bursa Efek Indonesia. Jurnal Studia Akuntansi Dan Bisnis, 4(3).

[4] Rumekso. 2009. Housekeeping Hotel- Floor Section. Yogyakarta: Penerbit. Andi.

[5] Rustami, P., Kirya, I. K., \& Cipta, W. 2014. Pengaruh Biaya Produksi, Biaya Promosi, Dan Volume Penjualan Terhadap Laba Pada Perusahaan Kopi Bubuk Banyuatis. Jurnal Manajemen Indonesia, 2(1).

[6] Soritua, Y. 2017. Analisis Peran Sektor Pariwisata Menjadi Pendapatan Utama Daerah (Studi Banding: Peran Sektor Pariwisata di Provinsi Bali). Referensi: Jurnal Ilmu Manajemen dan Akuntansi, 3(2), 1-7.

[7] Sugiyono. 2014. Metode Penelitian Kuantitatif Kualitatif dan R\&D. Bandung: Alfabeta.

[8] Sugiyono. 2015. Metode Penelitian Manajemen. Bandung: Alfabeta.

[9] Wachyuni, S. S., Wiweka, K., \& Liman, M. 2018. Pengaruh Online Distribution channels (ODS) terhadap hotel revenue. Journal of Tourism and Economic, 1(2).

[10] Yoeti. 2003. Tours and Travel Marketing. Jakarta: Pradnya Paramita. 